\title{
『新編魯般営造正式』に㧍ける魯般尺法と圧白尺法に関する研究 STUDY ON LUBAN RULER AND YABAI RULER IN THE BOOK OF XINBIAN LUBAN YINGZAO ZHENGSHI
}

\author{
朱 寧 寧* \\ Ningning ZHU
}

\begin{abstract}
Xinbian Luban Yingzao Zhengshi was written by craftsmen during the Yuan Dynasty (A.D1271 A.D 1368). The present study suggested that two "divination rulers" were used to design constructions, gates and doors. One was called the "Luban Ruler", and another was the "Yabai Ruler". This study clarified the relationship between the two rulers and measurements of the houses, gates and doors, which were written in this book.
\end{abstract}

Keywords : Xinbian Luban Yingzao Zhengshi, Luban Ruler, Yabai Ruler; Measurement of house building, History of Chinese Architecture, Architectural books

新編魯般営造正式, 魯般尺法, 圧白尺法, 民家架構寸法, 中国建築史, 建築技術書

\section{1. はじめに}

\section{1 研究背景と目的}

『新編魯般営造正式』は工匠が中国南部の建築技術について記し た書籍である。現在唯一の版本は寧波の天一閣に所蔵されている。 全文6巻、72ページ、4500字程度で、図版22枚を含む。

本書は中国南方の『営造法式』と呼ばれ、中国南方建築史にとっ て、重要な研究的価値を持つ文献である。本書の研究は1930年代に 始まった。郭湖生によって、本書の成立年代は元代であり1、明代の 『魯班経』の祖本の一つであると述べた。以上の点は学会で通説と されている。また、郭は本書が、福建地方で記されたものとした。 郭湖生の校勘記入2を筆者が整理し、全文解釈を行ったところ、記述 の中に見られる建築部材がすべて福建地方特有の部材名が使われる

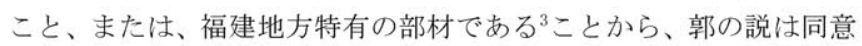
できるものである。

本書は内容的に8部 ${ }^{4}$ から構成され、その中の「魯般尺法および圧 白尺法」と「門および構架尺寸」が最も主要なものであり、明代の 日用の類書 ${ }^{5}$ 『魯般経』に数多く引用された。「尺法」とは尺の制 度、用法、法則などを指す。中国では尺法中に卜占の意味が含まれ るが、魯般尺法および圧白尺法は最も一般的に見られるもので、門 と民家の架構の寸法を決定する際に用いられる。本書は魯般尺法と 圧白尺法について記載される中国古籍の中で最も詳細なものの一つ である。本書中の「門および構架尺寸」は尺法を説明するための具 体的な寸法の例であり、尺法研究に貴重な寸法根拠を提供している。 中国建築史の中でも、民家建築史においては、尺法の研究が基礎 的な課題である。魯般尺法と圧白尺法に関する既往研究の内に、代 表的なものは陳輝東 ${ }^{6}$ 、程建軍 ${ }^{7}$ 、李哲揚 ${ }^{8}$ どにより行われてきたが、
以下の 3 点が問題点と考える。

1）両種の尺法に関する既往研究は、部分的な文献史料の解読によ っており、未だ総体的に文献史料を網羅した研究と結論は出されて いない。

2) 本書は最も詳細な尺法に関する史料で、特に具体的な尺法と合 う寸法の例も本書中の「門および構架尺寸」に書かれるが、これに 関する研究はそれほど専門的、詳細には行われておらず、尺法研究 分野の基礎となる本書における尺法に関する総体的な研究はまだ行 われていない。

3）地域遺構の尺法復原研究は史料の総合が不十分で、かつ見解が 不統一な既往研究を根拠にしており、その復原の結果も、様々な議 論をおこしている。

本論はいくつかの史料における尺法について例をあげ、総合的に 比較した上で、本書の尺法について、詳細な分析研究を行い、元代 の中国南部建築に見られる両種の尺法の使用方法を明らかにしよう とするものである。そして、中国および周辺国家に見られる両種の 尺法研究と遺構の復原研究に基礎を提供しようと試みるものである。

\section{2 研究内容と方法}

本論の研究内容は既往研究を基礎とし、原文解読を通して「魯般 尺法および圧白尺法」の尺法原理を分析する。そして、「門および 構架寸法」に対する寸法検証や他の史料における尺法や先行研究の ヒヤリングの結果をその尺法原理と比較する。更に、本書中の尺法 内容の編纂背景、即ち、元代福建地区における尺法の伝播と変化、 また魯般尺法と圧白尺法の使用が建築設計に及ぼす影響と意義の考 察を試みたものである。本論の研究方法は、本書中の尺法原理を注 釈し、寸法值を尺法にあてはめ分析し、他の史料に記載される尺法

\footnotetext{
* 早稲田大学創造理工学術院建築学専攻 博士後期課程 $\cdot$ 工修
} 
内容をまとめ、既往研究の尺法に関するヒヤリングの結果を説明す ることである。以上四点の結果を比較し、福建地方の尺法の変遷に ついて考察を試みる。

\section{2. 尺法の概念について}

\section{1 尺法の概念}

尺法は中国古籍文献中に、魯般尺法、飛白尺法 (即ち、圧白尺法)、 玄女尺法など、様々な卜占の意味を持つ尺法の記載が見られる。表 1 にこれらの尺法史料をまとめた。その中でも、魯般尺法と圧白尺 法が最もよく見られる。

\section{2 魯般尺法の概念}

魯般尺（または魯班尺）の名は魯般が発明したことに由来すると されるが、その起源はよく分かっていない。これは吉凶ト占の意味 を持つ尺法であり、1 尺の間を八分し、「財病離義官劫害吉」の八字 をあて、「財義官吉」は吉、「病離劫害」は凶とする。寸法を測る際 にその長さがあたる文字により、寸法に吉凶の意味を付け加える。 魯般尺法は中国南方を中心として、広い地域で使用されている。日 本およびベトナムの文献史料にも魯般尺の記載が見られ、実際に使 用された魯般尺が現存する ${ }^{9}$ 。

\section{3 圧白尺法の概念}

「圧白」は、程建軍の研究によれば、九星 ${ }^{10}$ には九色が当てはめ られ、1 から 9 までの数字に対応し、それぞれ「一白二黒三碧四緑 五黄六白七赤八白九紫」となる。その数字と色の対応関係は『造命 宗鏡集』に書かれている（図 1)。その内の「白」（即ち 1、6、8） は吉であり、「紫」(即ち9）は「小吉」、そのほか（即ち 2、3、4、5、 7）は「凶」とされる。文献資料によれば、圧白の方法はまた九星白 法11とも称される。「圧白尺法」とは寸法を「白」にあたる数字にあ わせること、即ち、1、6、8 の数字を選んで使うことである。寸の 位をこれらの数字にすることを「的」と呼ぶ。即ち、1 寸、6 寸、 8 寸を吉と寸ることである。同じ原理で、「尺白」は尺を基準単位と して、 1 尺、 6 尺、 8 尺を吉とすることであり、「分白」は分を基準 単位として、1 分、 6 分、 8 分を吉とすることである。「圧白尺法」 は中国広東省東部、福建省南部、浙江省、江蘇省、江西省、安微省、 台湾省などで使用されている12。張玉瑜の調查によれば、福建の工 匠は「圧白」を「合白」とも呼ぶ 13 。沖縄の「唐尺」 14 の裏面にも「圧 白尺法」と「魯般尺法」を併せて使う方法が書かれている。

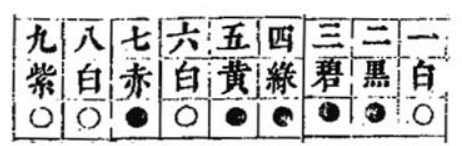

図1『造命宗鏡集』における数字と色の対応関係

\section{3．尺法に関する史料のまとめ}

魯般尺法と圧白尺法は地域や時代によって異なり、また多様な使 用方法と規則を持つ。以下に文献史料をあげ、比較を行う。

文献史料を見比べれば、魯般尺には様々な種類があることが分か る。1 尺は造営尺の 8.8 寸〜 14.4 寸に相当する（表 2)。八字につい ては、「病離」の順序が相反し(『造命宗鏡集』)、また「吉」を「本」 とする魯般尺も存在する(『事林広記』、造命宗鏡集』、揚州畫舫録』、 『三農紀』)。八字の吉凶の比率は 4 吉、4凶とするものの他に、「財
吉」が吉、「病離義官劫害」は凶、吉凶の比率は $1: 3$ とする史料も ある(『三農紀』)。

同様に圧白法に関する文献史料をまとめると、表 3 になる。「圧白 尺法」は寸法值と九色、および吉凶に対応寸るように用いられる。 尺法以外、方位、時間の数も九色の吉凶に対応して、ト占として用 いられる (『讀書紀數略』、『造命宗鏡集』、『揚州畫録』)。

\section{4. 『新編魯般営造正式』における尺法原理}

本書の具体的な内容は 45 項目 ${ }^{15}$ から構成される。「魯般尺法およ び圧白尺法」の内容は、第 $6,7,8,9,10,11,18,19$ 項目に記述され、 以下に両種の尺法の使用方法について解読する。なお、その原文と 注釈を注に載せた。

\section{1 尺法原理の解読}

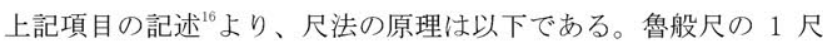
は営造尺の 1.44 尺であり、1 尺の間には「財病離義官劫害吉」の八 字があてられ、魯般尺は門を造る時に用いられるということが分か る。曲尺の 1 尺は 10 寸に分かれ、1 寸は 10 分に分かれる。寸法值 には色が対応しており、1、6、8を白（吉）、9を紫（小吉）とし、 その四つの数字が吉数となる。「本」字が「吉」又は「財」の替わり となり、用いられることもある。架構および門の構造の高さ、長さ などの寸法に圧白尺法を用いる。門および架構における圧白尺法は 魯般尺法と併せて用いる必要がある。本書の項目 6、10 には尺法を 説明するための「曲尺之図」と「魯般真尺図」があり、これより復 原図を作成した（図 2、図 3)。

\section{2 「魯般尺詩八首」の解読}

第 7 項目の「魯般尺詩八首」では、魯般尺の八字から八首の詩が 作られており、全体で 30 行となる。八首詩中、八字にはそれぞれ、 「吉祥」「入財」「昇官」「孝順」「分離」「病気」「被害」「被盗」の異 なる人生の意味が宛てられ、住宅平面の中の大門〜廊門の 8 種の門 に対応しており、これをまとめると、表 4 の 18 項 $(A \sim R){ }^{17}$ となる。 この八字は単純に 4 凶 4 吉に分かれているのではなく、大吉、小吉、 小凶、大凶という 4 つの等級を持つ。大吉（「財」、「吉」）はすべて の門に用いることが可能で、小吉（「義」、「官」）は吉ではあるが、 門の種類によっては不適切の場合もある。小凶（「病」「「離」）は凶 だが、門によっては用いてもよい場合もある。大凶（「害」、「劫」） は、いずれの場合も用いてはならないとされる。具体的に、小吉の うち「義」は、廊門 (L) に用いてはならず、中門 (K) では吉が凶 に転ずる可能性があり、厨門 (M) にのみ用いることができる。「官」 は大門 $(\mathrm{N})$ に用いてはならず、房門（0）に用いた場合は凶となる 可能性がある。小凶のうち「病」は㰾門 $(G)$ に用いることができる。 以上のような八字と八門の対応関係より、福建省の典型的な住宅平 面における対応図（図 4) を描き出すことができる。

\section{5. 尺法原理と他の史料の尺法の比較}

上記原文の解読から分かった本書の尺法原理と他の史料における 尺法の比較を行うと、本書中の魯般尺が営造尺に対応する長さは一 番長い (14. 4 寸)。一尺の内の八字の種類は 3 組、吉凶分類が 4 組 あり（表 2 の卯）、他の史料の記載より複雑である。一方で、本書 中の圧白法は時間と方位に関わらず、寸法だけで使い(表 3 の!卯)、 他の史料の記載より簡単な方法となっている。 
表 1 文献史料別「尺法」のまとめ

\begin{tabular}{|c|c|}
\hline 文献史料書名 & 尺法に関する記載 \\
\hline [宋]事林広記 ${ }^{18}$ & 魯般尺法、飛白尺法 \\
\hline [元] 居家必用事類全集 ${ }^{19}$ & 開門尺法、魯般尺法 \\
\hline [明]宅䆩經 ${ }^{20}$ & 九天玄女裝門尺法 \\
\hline [明]魯班經 ${ }^{21}$ & 大抵尺法各隨匠人所傳術者 \\
\hline [清]揚州畫舫録 ${ }^{22}$ & 古尺法為十五種 \\
\hline [清]阳宅十書 ${ }^{23}$ & 用門尺法 \\
\hline [元] 新編魯般営造正式 ${ }^{24}$ & 凡人造門, 用依尺法也 \\
\hline
\end{tabular}

表 2 文献史料別「魯般尺法」のまとめ

\begin{tabular}{|c|c|c|c|c|c|}
\hline 文献史料書名 & 尺名 & 尺長 & 字長 & 八字 & 吉凶 \\
\hline $\begin{array}{l}{\left[\text { 宋] 事林広記 }{ }^{25}\right.} \\
\text { [元]居家必用事類全集 }\end{array}$ & 魯般尺 & 12 寸 & $\begin{array}{l}1.5 \\
\text { 寸 }\end{array}$ & 財病離義官塕害吉 & $1: 1$ \\
\hline & 同上 & 同上 & 同上 & 同上 & 同上 \\
\hline [宋] 事林広記 ${ }^{27}$ & 魯般尺 & 11 寸 & \begin{tabular}{l|}
1.37 \\
5 寸
\end{tabular} & 財病離義官却害本 & $1: 1$ \\
\hline [明]造命宗鏡集 ${ }^{28}$ & 魯班尺 & & & 財離病義官却害本 & $1: 1$ \\
\hline $\begin{array}{l}\text { [清] (同治) 蘇州府 } \\
\text { 志 }^{29}\end{array}$ & 魯班尺 & 8. 8 寸 & $\begin{array}{l}1.1 \\
\text { 寸 }\end{array}$ & & \\
\hline [清] 樂律表微 ${ }^{30}$ & 魯班尺 & 9寸 & $\begin{array}{l}1.12 \\
5 \text { 寸 }\end{array}$ & & \\
\hline [清] 揚州畫舫録 ${ }^{31}$ & 八字尺 & 14. 4 寸 & $\begin{array}{l}1.8 \\
\text { 寸 }\end{array}$ & 財病離義官劫害本 & $1: 1$ \\
\hline [清] 三農紀 ${ }^{33}$ & 魯班尺 & & & 財病離義官劫害本 & $1: 3$ \\
\hline $\begin{array}{l}\text { [元]『新編魯般営造正 } \\
\text { 式』 }\end{array}$ & 魯般尺 & 14. 4 寸 & $\begin{array}{l}1.8 \\
\text { 寸 }\end{array}$ & $\begin{array}{l}\text { 財病離義官规害吉 } \\
\text { 財病離義官胠害本 } \\
\text { 本病離義官却害吉 }\end{array}$ & $\begin{array}{l}1: 1: 1 \\
: 1 \text { 注 }^{34}\end{array}$ \\
\hline
\end{tabular}

表 3 文献史料別「圧白法」のまとめ

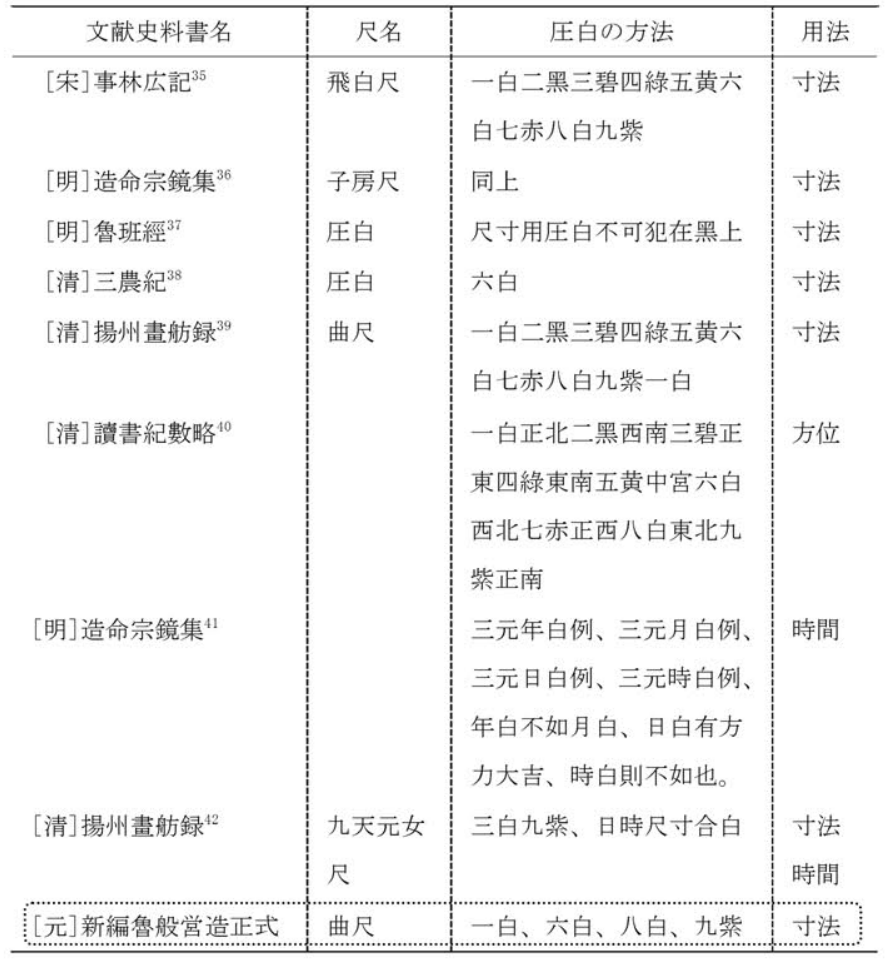

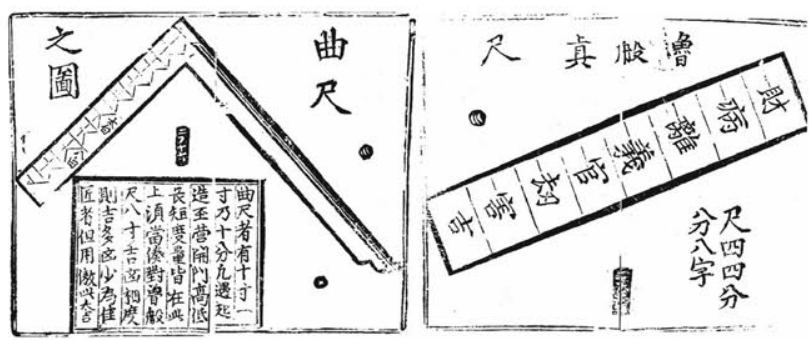

図 2 原文における「曲尺之図」と「魯般真尺図」

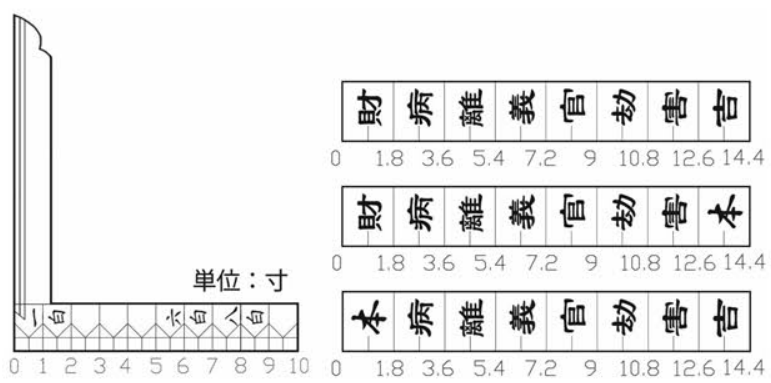

図3＼cjkstart原文による曲尺と魯般真尺の復原

表 4 「魯般尺詩八首」における「八字凶吉」と門の対応 関係

\begin{tabular}{|c|c|c|c|c|c|c|c|c|c|}
\hline \multicolumn{2}{|c|}{ 吉凶 } & 大門 & 外門 & 中聞 & 内門 & 房門 & 厨門 & 則門 & 廊門 \\
\hline \multirow[t]{2}{*}{ 大吉 } & 吉 & & & $\mathrm{RO}$ & & & & & \\
\hline & 財 & $\mathrm{CO}$ & $\mathrm{AO}$ & $\mathrm{BO}$ & & $\mathrm{DO}$ & & & \\
\hline \multirow[t]{2}{*}{ 小吉 } & 義 & & & $\mathrm{K}($ & & & $\mathrm{MO}$ & & LO \\
\hline & 官 & $\mathrm{N}$ & & & & 00 & & & \\
\hline \multirow[t]{2}{*}{ 小凶 } & 病 & & $\mathrm{E}$ & $\mathrm{F} \bigcirc$ & & & & ${ }_{\mathrm{G}} \mathrm{D}$ & \\
\hline & 離 & & $\mathrm{H} \bullet$ & $\mathrm{I}$ & & $\mathrm{J}$ & & & \\
\hline \multirow[t]{2}{*}{ 大凶 } & 害 & & $\mathrm{P} \bullet$ & & $Q$ & & & & \\
\hline & 劫 & & & & & & & & \\
\hline
\end{tabular}

凡例 : ○は良い。数字は良いが、門によっては凶、禁止。数字 は悪いが、門によっては、使えるまたは悪さが減る。は亜い、禁止。 $\mathrm{A} \sim \mathrm{R}$ は注 16 を参照。

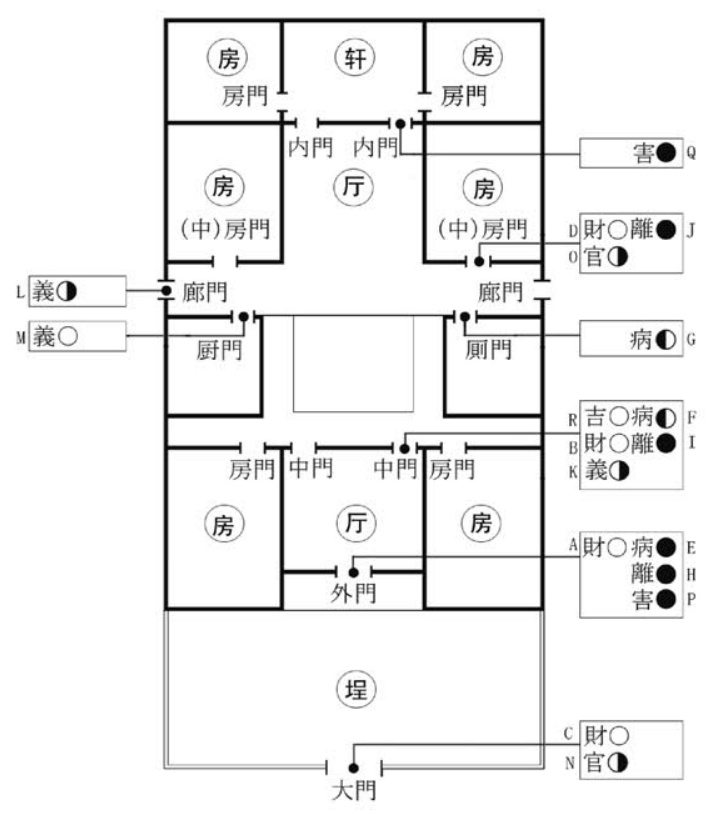

図4 平面図から見る「魯般尺詩八首」における「八字凶吉」 と門の対応関係 (凡例は表4と同じ) 


\section{6. 『新編魯般営造正式』における尺法検証}

前節の 4.1 の【尺法原理の解読】によって、魯般尺法と圧白尺法 が門と架構の寸法に用いられることは確認できた。しかし、本書の 「門および架構寸法」(項目 6,15,18,22,24)に記載される寸法に二つ の尺法が実際に適用しているのかを検証する必要があると考える。 そこで、本書における門と架構寸法の吉凶の割合を見ることを通じ て、尺法の使用方法を分析する。

\section{1 門寸法の吉比率}

第6項目「魯般真尺」 ${ }^{43}$ の中に示される八個の門の寸法は、それぞ れ $0.8,21,28,42,43.1,43.8,56,56.6$ 寸である（表5の(1)。21, 28, 56 寸の寸法は末尾がそれぞれ1寸、8寸、6寸である。また $0.8,43.1,43.8$, 56.6寸の末尾は8分、1分、8分、6分である。これらの寸法はみな「圧 白」であり、末尾が寸の単位になる場合を前述のように「寸白」と 呼び、末尾が分の単位の場合は「分白」と呼ぶ。その内にただ一つ の例外である、42寸の末尾である2寸は「二黒」を示すが、これは悪 い例としてあげられたものである。魯般尺上の寸法には財、吉、義 があてられている(その内に財、吉は7 個、使用率は $87.5 \%$ 、最も用い る)。42寸の例外を除くと、門の寸法は圧白尺法および魯般尺法で共 に吉であり、即ち、全寸法における吉の寸法の比率（本論では「吉 比率」と呼ぶ）は $100 \%$ である（図5のA-1、図5のA-2）。

\section{2 架構寸法の吉比率}

第 $15,18,22,24$ の四つの項目 ${ }^{44}$ で、「三架、五架、七架、九架」の 4 組の架構形式と、「歩柱、仲柱、棟柱、架媣、心間、次間」 ${ }^{45}$ の六 つの寸法值の組み合わせで、20 個の寸法が示されている(表 5 の (2))。 これらの寸法を圧白尺法に当てはめると、圧白になる寸法は 18 個、 圧白にならない寸法は 2 個（143、43 寸）となる。魯般尺法上で吉 となる寸法は 13 個、凶となるのは 7 個（111、46、126、206、48、 220、148 寸）である。圧白尺法での吉比率は 90\%（図 5 の A-3）、 魯般尺法での吉比率は $65 \%$ である (図 5 の A-4)。各柱間の寸法值を 加えると、「総架媣」、「総面闊」 ${ }^{46}$ の值が分かり、それらは 7 個の寸 法值となる ${ }^{47}$ (表 5 の(3)。このうち、圧白尺法で吉が 4 個, 凶が 3 個（313、415、344 寸）である。魯般尺法では吉が 3 個，凶が 4 個 （168、313、378、415 寸）となる。圧白尺法での吉比率は $57.1 \%$ （図 5 の A-5)、魯般尺法上の吉比率は $42.9 \%$ である（図 5 の A-6）。

以上の架構寸法または架構全体寸法における「圧白」とする寸法 は全て「寸白」ということが確認できる。

\section{3 吉比率の比較検証}

6.1 の門寸法の吉比率】で示した二組の吉比率および 6.2 の【架 構寸法の吉比率】で示した四組の吉比率と任意の数字が圧白尺法に おける「白」となる可能性 $40 \%{ }^{48}$ 、魯般尺法における「財義官吉」 となる可能性 $50 \%{ }^{49}$ を図 5 にまとめて示す。3 組（図 5 の B-2）にお ける吉比率（即ち架構寸法における魯般尺法、架構全体寸法におけ る圧白尺法、架構全体寸法における魯般尺法）は、それぞれ $65 \%$ 、 $57.1 \% 、 42.9 \%$ となり、任意寸法に対する吉比率に近い、或いはそ れを下回るため、これら 3 組では圧白尺法あるいは魯般尺法を用い ていないことが推測される。そのほかの 3 組 (図 5 のB-1) の吉比 率（即ち、門寸法における圧白尺法と魯般尺法、架構寸法における 圧白尺法）は、それぞれ $100 \%$ 、100\%、90\%となり、任意寸法に対 する吉比率の 2 倍以上となるため、これら 3 組では圧白尺法あるい は魯般尺法が用いられていると推測される。
表 5 尺法における門と架構寸法の凶吉のまとめ（単位 : 寸)

(1)門寸法

\begin{tabular}{|c|c|c|c|c|c|c|c|c|}
\hline 指定項目 & 0.8 & 21 & 28 & 42 & 43.1 & 43.8 & 56 & 56.6 \\
\hline \multirow[t]{4}{*}{ 門 } & 八白 & 一白 & 八白 & 二黒 & 一白 & 八白 & 六白 & 六白 \\
\hline & 0 & 0 & O & 0 & 0 & 0 & 0 & 0 \\
\hline & 財 & 義 & 吉 & 吉 & 吉 & 財 & 吉 & 吉 \\
\hline & 0 & 0 & 0 & 0 & 0 & 0 & 0 & 0 \\
\hline \multicolumn{7}{|c|}{ (2)架構寸法 } & \multicolumn{2}{|c|}{$\begin{array}{l}\text { (3)架構全 } \\
\text { 体寸法 }\end{array}$} \\
\hline 指定項目 & 歩柱 & 仲柱 & 棟柱 & 架深| & 心間 & 次間 & $\begin{array}{l}\text { 総架 } \\
\text { 梁 }\end{array}$ & $\begin{array}{l}\text { 総面 } \\
\text { 闊 }\end{array}$ \\
\hline \multirow{5}{*}{$\begin{array}{l}\text { 三架後 } \\
\text { 連一架 }\end{array}$} & 101 & & 121 & 56 & 111 & 101 & 168 & 313 \\
\hline & 一白 & & 一白 & 六白 & 一白 & 一白 & 八白 & 三緑 \\
\hline & O & & 0 & 0 & 0 & 0 & 0 & 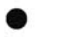 \\
\hline & 財 & & 義 & 吉 & 劫 & 財 & 劫 & 劫 \\
\hline & 0 & & 0 & 0 & 0 & 0 & 0 & 0 \\
\hline \multirow{5}{*}{$\begin{array}{l}\text { 五架拖 } \\
\text { 後一柱 }\end{array}$} & 108 & 128 & 151 & 46 & 136 & 121 & 230 & 378 \\
\hline & 八白 & 八白 & 一白 & 六白 & 六白 & 一白 & 十白 & 八白 \\
\hline & 0 & O & 0 & O & 0 & 0 & O & 0 \\
\hline & 義官 & 吉 & 義 & 病 & 義 & 義 & 吉 & 病離 \\
\hline & 0 & 0 & 0 & O & 0 & 0 & 0 & 0 \\
\hline \multirow[t]{5}{*}{ 正七架 } & 126 & & 206 & 48 & 143 & 136 & 288 & 415 \\
\hline & 六白 & & 六白 & 八白 & 三緑 & 六白 & 八白 & 五黄 \\
\hline & 0 & & 0 & 0 & O & 0 & 0 & O \\
\hline & 劫害 & & 離 & 離 & 吉 & 義 & 吉財 & 害 \\
\hline & 0 & & 0 & O & 0 & 0 & 0 & \\
\hline \multirow[t]{5}{*}{ 正九架 } & 136 & & 220 & 43 & 148 & & 344 & \\
\hline & 六白 & & 十白 & 三緑 & 八白 & & 四碧 & \\
\hline & 0 & & 0 & O & 0 & & 0 & \\
\hline & 義 & & 離 & 吉 & 離 & & 吉 & \\
\hline & 0 & & 0 & 0 & & & 0 & \\
\hline
\end{tabular}

凡例 : 寸法值の下の一行目は魯般尺法における吉凶である。その下の ○は吉の意味で、・は凶の意味である。次の一行目は圧白尺法におけ る吉凶である。○との意味は上と同じである。以上寸法吉凶の説明 は図 6 になる。

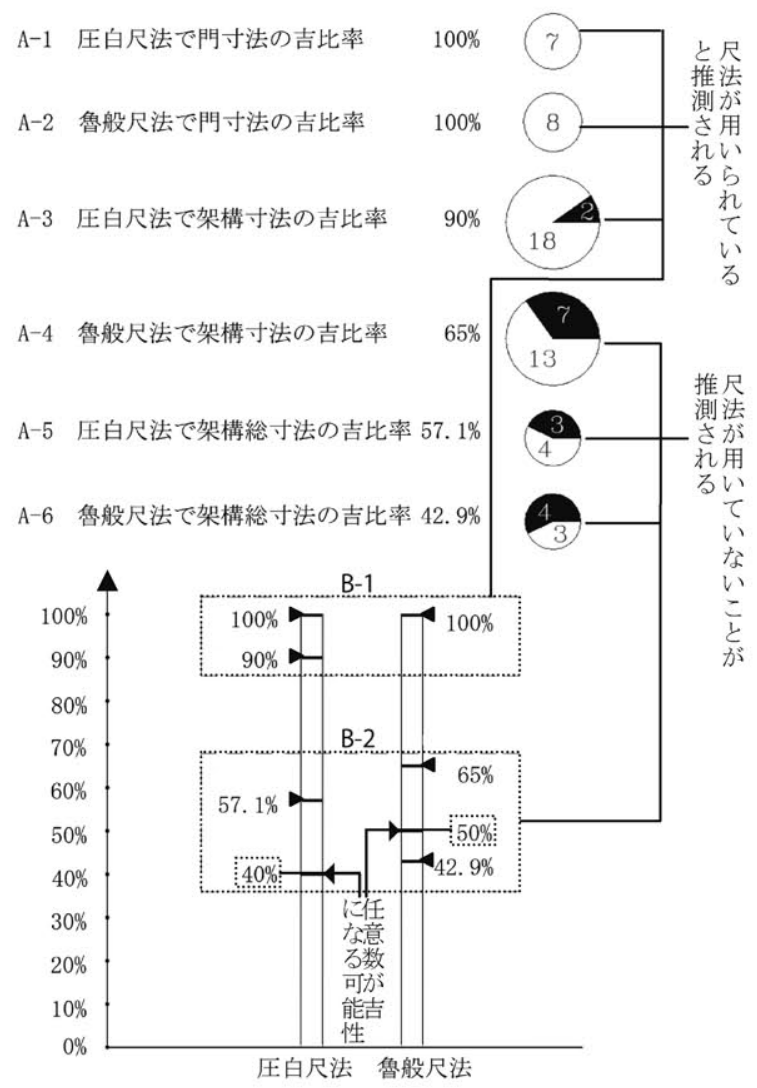

図 5 尺法における門と架構寸法の吉比率の比較 凡例 : 丸の中の白い部分には吉の寸法の数、黒い部分には凶の寸法の数。 


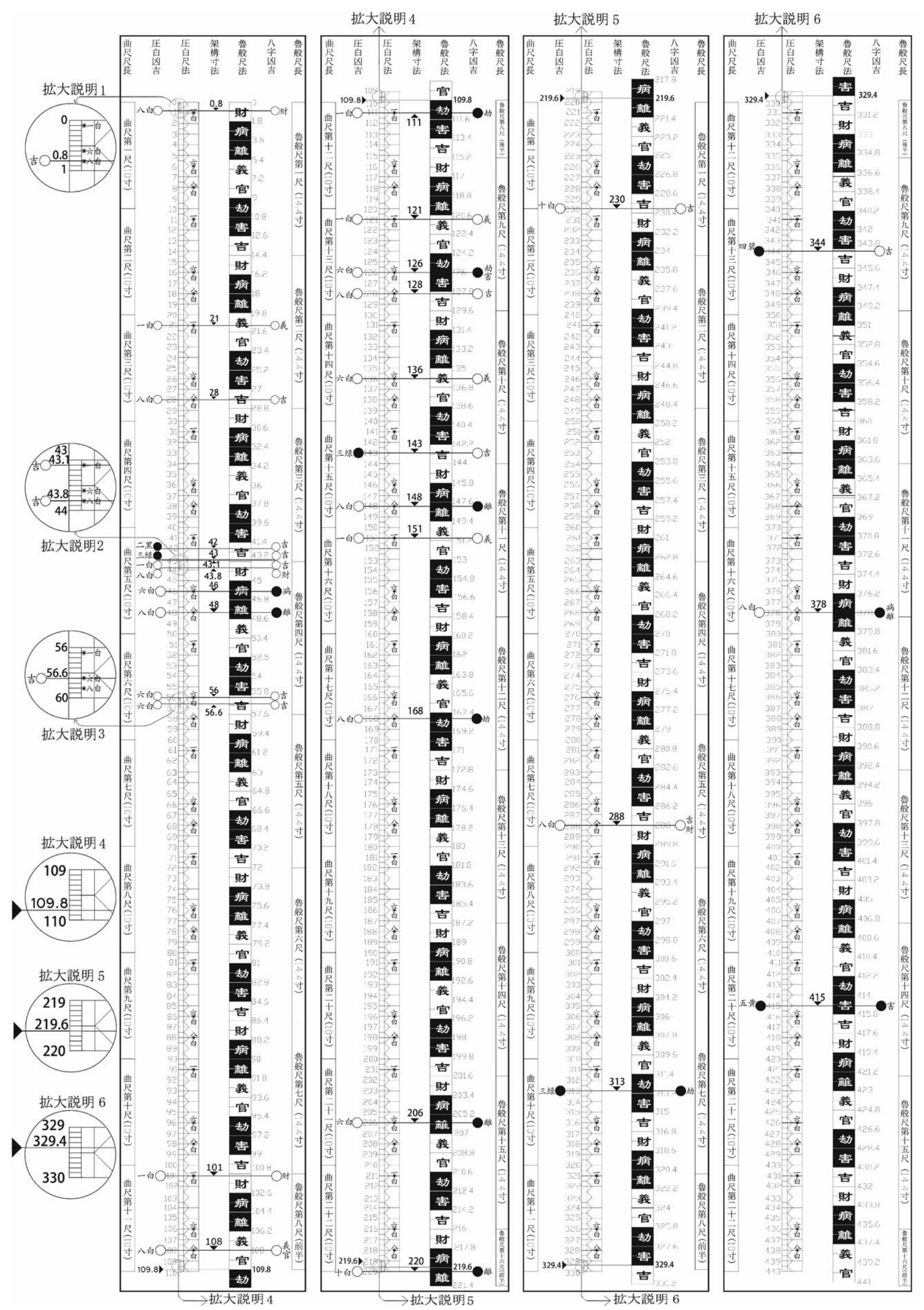

図 6 尺法における門と架構寸法の吉凶計算の説明50 
上記より、尺法検証の結果をまとめる。

1）魯般尺法は門に用い、圧白尺法は門および民家架構寸法に用い る。民家架構の全体寸法には魯般尺法も圧白尺法も用いない。

2）魯般尺法は、門を造る際、「吉」「財」の 2 文字を最も用いる。 圧白尺法は門を造る際、「寸白」と「分白」を用い、架構においては 「寸白」を用いる。

\section{7. 尺法原理と尺法検証の比較}

前節 6 の【尺法検証】から見られる検証結果と 4 の【尺法原理】 で見た尺法原理を比較すると、合致する点と合致しない点が出てく る(表 6 の(1) と (2)。

\section{1 尺法原理と尺法検証合致する点}

1） 4.1 の【尺法原理の解読】と 6.3 の【吉比率の比較検証】合致 する点を以下で述べる。 4.1 によって、魯般尺法と圧白尺法を併せ て、門に用いられる点は 6.3 の結果と合致する。又、 4.1 によって、 架構の部材寸法に圧白尺法が用いられ、6.3 の結果が示すように、 柱間と桁間に圧白尺法が用いられる。一見異なるように見えるが、 中国南方木造建築では、柱間、桁間の寸法は、梁、桁、貫など部材 の長さで決まる ${ }^{51}$ ので、部材の寸法と同じであり、2 項の結果が一致 する。

2） 4.2 の【魯般尺詩八首」の解読】と 6.1 の【門寸法の吉比率】 合致する点を以下で述べる。 4.2 によって、魯般尺法の八字には四 吉、四凶が含まれるが、造門時に使用できるのは「吉」、「財」のみ で、「官」、義」の使用は禁忌である。6.1 で示した 8 個の門の寸法 のうち、7 個は「吉」、財」の寸法を示して、4. 2 の結果と合致する。 ただ 1 個（21寸）が義字に当たて、表 4 に示したことから、この 21 寸(義)は厨門の寸法として用いることができる。

以上の比較は表 6 の(1)との三つの「合」で示される。

\section{2 尺法原理と尺法検証合致しない点}

4.1 の【尺法原理の解読】と 6.3 の【吉比率の比較検証】合致し ない点を以下で述べる。4.1 では、架構における圧白尺法は魯般尺 法と併せて用いる必要があるとした。一方、6.3 では圧白尺法は門 および民家架構に用いて、魯般尺法は架構に用いられないとした(表 6 の(1)と(2)の「不合」)。一致しない理由として、異なる方法が混在 していることが考えられる。これ尺法の混在について原文に「今時 匠人則開門, 䦗四尺二寸, 乃為 “二黑”, 般尺又在 “吉” 上」 ${ }^{52}$ の記 載もある。この文によって、当地の工匠は門を造る場合は、 42 寸を 用いており、4 寸瀂般尺法では「吉」、圧白尺法では「二黒」(凶) であることから、本書を編纂する時、当地では魯般尺法を用い、圧 白尺法の方法は用いなかったと推測される。用いなかった原因は、 魯般尺法は元代の福建地方の方法(表 6 の (4) で、圧白尺法は外部か ら転入され、まだ普及していなかった方法(表 6 の(3)) であるからだ と推測できる。その外部の伝入された圧白尺法は架構において上記 に合致しない 4.1 と6.3 から見える二つの方法であると考えられる。 即ち、一つは表 6 の1に見られる架構寸法における圧白尺法と魯般 尺法を併せて用いる使用方法であり、もう一つは表 6 の『に見られ る架構に圧白尺法のみが使われる方法である。その圧白尺法が架構 における二つの使用方法が異なる源流から福建省へ来ているか、ま たは福建省で異なる発展過程にあったかについては、本書の編纂過 程と福建省尺法の伝播関係 ${ }^{53}$ のテーマとして今後の詳細な研究が期
待される。尺法の差異以外にも本書中の「古」と違う「今」の技術 が記述されている ${ }^{54}$ これらの差異があるのも伝来された技術また は外来技術書の内容と当地の技術が同時に編集され、本書にまとめ られたためであると推測できる。さらに、本書の編纂過程と福建省 の建築技術変遷について今後研究が期待される。

\section{8. ヒヤリングや史料のまとめと尺法検証の比較}

魯般尺法と圧白尺法は建築で使用され、陳輝東は 1963 年と 1983 年の 2 回、福建の工匠に対して調查を行っている。それによれば福 建地区では時期は不明であるが、魯般尺法と圧白尺法の使用方法が 簡便化されていると述べている。それの簡便化の過程は三つの特徵 を持つ。

1）簡便化以前は、建築の方位から「尺白」、「白」の起点（数字 の 1 に対応する色）が決定され、長さを測ったが、簡便化されたも のは方位に関係なく、「尺白」を用いず、長さの寸を圧白（即ち「寸 白」）に当てはめるだけである。

2）簡便化以前は、建物の柱高、柱間や桁間寸法には圧白が求めら れ、梁行総間、桁行総間などにも圧白が求められる。簡便化以後は 総間の寸法に関わらず、それぞれの建物の柱高、柱間や桁間寸法を 圧白として吉とするのみである。

3）簡便化以前は、魯般尺法は門と架構の造営に用いられたが、簡 便化されて門にのみ用いられるようになり、現在の民家架構では用 いない。

上記三つの簡便化された技術の特徵（表 6 の(2)）は 6.3 の【吉比 率の比較検証】（表 6 の6)）の三つの結果と合致する。即ち、本書で 記述された寸法は一つの源流とする元代外部から福建省に伝入され た尺法を反映しており、陳輝東の尺法調査研究による簡便化後の尺 法と合致する。

表 6 本書とヒヤリングから見られる福建地方の尺法

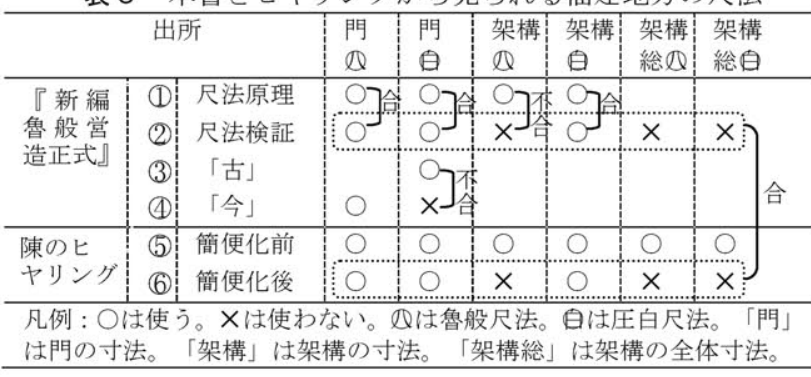

更に、7.2 の【尺法原理と尺法検証合致しない点】により、魯般 尺法は元代の福建地方の方法で、圧白尺法は外部から転入した方法 と推測できる。 5 の【尺法原理と他の史料の尺法の比較】によって、 本書中の魯般尺法は他の史料に記載される方法より複雑であり、圧 白尺法は他の史料の記載より簡単な方法である。以上によると、本 書の魯般尺法は元代福建地方で成熟していた複雑な方法で、圧白尺 法は外来の簡単な方法であると推測する。なお、福建地方に複雑な 圧白尺法（表 6 の(5)）の存在について詳しいヒヤリング及び文献研 究が期待される。

\section{9. 尺法の建築設計に対する影響と意義}

上記の研究を更に考察すると、魯般尺法および圧白尺法の建築設 
計に対する影響と意義は以下二点と考える。

1) 唐宋時代の遺構の寸法データを分析すると、柱間の寸法值は全 て尺の完数となっている。これに対し、両種の尺法の使用は、特に 圧白尺法中の「的」および「分白」の方法において、門および架 構の寸法を「圧白」にするために、「寸」と「分」の単位の数值を生 じさせたと考えられる。圧白尺法が建築設計方法に影響を与え「寸」 と「分」を生じさせた過程についてはさらなる研究を期待する。

2) 本書では魯般尺法の八字はそれぞれ人生の意味（「昇官」、「孝 順」など）を持ち、また住宅内の門が場所（房門、内門など）によ って性格の意味に対応し、他の文献より複雑な使い方となる。魯般 尺法の複雑化と住宅平面の門の性格の多様化の対応関係については 今後の研究を期待する。

\section{0. 結論}

『新編魯般営造正式』における「魯般尺法および圧白尺法」の解 読による尺法原理は、門および架構において、魯般尺法と圧白尺法 を併せて用いるものであり、門を造る時、魯般尺法では「吉」「財」 の2文字が最も用いられる。しかし、本書の「門および架構寸法」の 検証結果からは、門を造る時のみに魯般尺法と圧白尺法を併せて用 いることが確認できた。この検証結果によって、圧白尺法は「寸白」 と「分白」の 2 種の方法を用いる。架構を造る時、架構の柱高、柱間 や桁間には圧白尺法の「寸白」のみを用いることも分かった。

上記の尺法原理と寸法検証の比較において、両者が合致しない点、 本書に記載される「古」「今」尺法の差異点、および他の史料におけ る尺法との比較の三点から、本書中の魯般尺法は、元代の福建地方 の方法であり、圧白尺法は、外部から福建地方へ転入した方法と推 測できる。

「門および架構寸法」の検証結果で示した尺法の使用は、陳輝東 の福建省調査で明らかになった、簡便化された尺の用い方と同じで あることが示せた。なお、設計方法において圧白尺法が柱間の完数 制からの変化をもたらした可能性を示し、魯般尺の八字が人生の意 味をもち、それが住宅の門の性格を対応していることも示せた。

本研究が基礎となり、尺法の変遷や本書の成立過程などについて の今後の研究が進展することを期待する。

\section{謝辞}

本論文は修士論文『「新編魯般営造正式」注勫与研究』(参考文献 15）を発展させたものである。本研究は 2008 年 10 月より、文部科 学省の国費奖学金を得て、実施した。本論文の執筆には、指導教官 早稲田大学理工学術院中川武教授の指導と、研究室 $0 B$ の高野恵子氏、 研究室助手の米澤貴紀氏の協力をいただいた、ここに記して感謝申 し上げる。

\section{参考文献}

\section{中国語参考文献}

1) 劉敦楨 : 明『魯般営造正式』抄本校讀記, 中国営造匯刊, 第 6 卷第 4 期, pp. $162-164,1937.6$

2）劉敦楨：魯班營造正式, 文物, 1962 年第 2 期, pp. 9-11

3）郭湖生：關於『魯般營造正式』和『魯班經』,科技史文集（七）, pp. $98-105,1981.6$

4）郭湖生：『魯班經』評述, 中國古代建築技術史, 科學出版社, pp. $541-544,1985$
5）陳從周: 影印明『魯般營造正式』序, 明魯般營造正式, 上海科學技術出版社, 1985

6）新鍈京版工師雕摡正式魯班木經匠家鏡三卷, 明萬歷刻本, 日本東京内閣文 庫に収藏

7) 新刻京板工師雕鎪正式魯班經匠家鏡三卷 (郭湖生先生の較勘記入を含む), 清刻本, 藏于東南大學建築系古籍圖書室

8）張權裒, 郭湖生等主編：中國古代建築技術史, 科學出版社, 1985

9）程建軍：「圧白」尺法初探, 華中建筑, pp. 47-59, 1988 年 2 期

10) 程建軍, 孔尚朴: 風水與建築, 江西科学技術出版社, 2005 年 1 月第 2 版

11）李乾朗：台湾古建築図解事典, 台北, 台湾館編輯制作, 2003.7

12）陳耀東 : 魯班経匠家鏡研究, 中国建築工業出版社, 2010.4

13）李哲揚：潮汕伝統建築大木構架研究, 華南理工大学博士論文, 2005.4

14）張玉瑜：実踐中的営造智慧一一福建傳統大工匠師技藝搶救性研究, 東南 大学博士論文, 2004.12

15）朱寧寧：『新編魯般営造正式』注釈与研究, 東南大学修士論文, 2004.12 日本語参考文献

16）浅川滋男: 中国の民家 - 住居史研究, 建築史学, 第二十号, pp. 102-126, 1993.3

17）田中淡: 中国の伝統的木造建築, 建築雑誌, vol. 98, №. 1214, pp. 32-35, 1983. 1

18）䆶德忠:唐尺と魯般尺, 宗教学論集 (19), pp. 69-80, 1996.7

19）安田徽也: 魯般尺に関する文献調查, 日本建築学会大会学術講演梗概 集, F-2, pp. 105-106, 2004. 8

20）清末隆廣, 中川武, 白井裕泰, 中沢信一郎, 坂本忠規, 中村泰一, ものさし について (III) : ヴィエトナム/フエ・阮朝王宫の復原的研究 (その 70) (建 築歴史・意匠) 研究報告集 II, 建築計画 ・ 都市計画 ・ 農村計画 - 建築経 済・建築歴史・意匠 (73), pp. 529-532, 2003.2. 28

21）朱寧寧：『新編魯般営造正式』の注䣋と研究, 日本建築学会大会学術講 演梗概集, F-2, pp. 453-454, 2010.7

注

注1) 参考文献 3) p. 101 郭湖生（1931-2008、中国の建築史家、東南大学教授） の研究により、『新編魯般営造正式』の中の「某路某県某郷某里某社」は 元代の行政区名であることが分かる。これによって、『新編魯般営造正式』 の製本年代は元代と推測できる。

注2) 郭湖生は 1980 年代に東南大学の建築史研究室に収藏されている清の版 本の『魯班経』（南工本『魯班経』と呼ばれている）中に、校勘記入をし た。この本と郭湖生の記入は現在未刊行である。

注3)参考文献 15）より、「寿額」、「槽門」、「偃桷」、「直板垂魚」、「斗 叉童」、「斗磉」、「次棟」などは福建地方で使われた建築部材の名称で あり、または、福建地方に特有の部材である。

注4)順に、「営造儀礼」、「水平道具」、「尺法凶吉」、「構架寸法」、「相 宅」、「造門」、「細部」、「畜圈」である。

注5) 例えば『三台萬用正宗』、『萬用正宗不求人』、『五車拔錦』など。

注6) 参考文献 12) 陳耀東が『魯班経』を中心として福建地方の尺法に関する 研究を行った。

注7）参考文献 9）、10）程建軍が中国風水学における建築の尺法に関する研究 を行った。

注8)参考文献 13) 李哲揚が中国広東省潮汕地方の伝統建築の架構における圧 白尺法と魯般尺法の使用に関する研究を行った。

注9）参考文献 19）、20)

注10)参考文献 9) p. 47 によって、北斗七星とそれに付属する二つの星を加え、 北斗九星とする。堪興家はこれを根拠とし、堪興九星、即ち貣狼, 巨門, 禄存, 文曲, 廉貞, 武曲, 破軍, 左輔, 右㣂を発展させた。

注11）[晋] 郭璞『葬書』（清文淵閣四庫全書本）では九星白法に関する記載は 以下である。「淺深世俗多用九星白法以定尺寸、謬也。」

[宋] 蔡元定『發微論』（清文淵閣四庫全書本）では九星白法に関する記載 は以下である。「淺哚篇:經曰地吉葬|、與重屍同。正此義也、世俗裝卦例、 論九星白法以定寸尺者大謬也。」

注12) 参考文献 10) p. 146

注13) 参考文献 14) p. 133

注14)参考文献 18） p. 74 より、沖縄に残る「唐尺」の裏面に書いている魯般 尺法と圧白尺法を併せては使う方法は以下である。「此真正魯般尺。乃公 輸子所製。内包羅造化。弁別吉凶。凡賢造安墳。以及神合龍（龍は字能の 誤記）用家司什物。船只散倉。凡天下有尺寸之物。皆經此尺。其間度用取 一尺四寸四分。用財義官本病離劫害八字。財義官本可用。病離劫害不可用。 
凡量物, 開二尺一寸為一白在尺内為義字上。二尺八寸為八白。合尺内吉上。 用四尺二寸一分合四綠。一白在本上。用四尺三寸八分合財字。能依此法。 萬無一失。以右手用尺。將財德為首。依字脚向外。從便取法。」

注15)『新編魯般営造正式』の内容は具体的な項目としては以下の 45 である: （前脱三頁） 1 請設三界地主魯般仙師文、 2 詩日、 3 定盤真尺、 4 詩日、 5 断 水平法、 6 魯般真尺、 7 魯般尺詩八首、 8 本門詩曰、 9 曲尺詩、 10 曲尺之図、 11 推起造向首合白吉星、12 凡伐木克択日辰興工、13 推匠人起工格式、 14 推造宅舍吉凶論、15 三架屋後連一架、16 詩曰、17 画起屋様、18 五架房子 格、19 詩曰、 20 造屋間数吉凶例、 21 歌日、 22 正七架三間格、 23 詩、 24 正 九架五間堂屋格、 25 詩日、 26 秋遷架、 27 小門式、 28 梭焦亭、29 詩、30 詩 日、31 詩曰、32 拠仙賢云、3 3 郭璞相宅詩三首、34 詩、35 又歌曰、36 造門 法、37 起庁堂門例、38 詩曰、39 諸様垂魚正式、40 駝峯正格、41 五架屋諸 式図、42 五架後拖両架、 43 正七架格式、44 占牛神出入、45 五音造羊栈格 式。

注16)項目 6、9、10、11、18、19 の原文と注釈は以下である。

【項目 6】「魯般真尺」魯般尺乃有曲尺一尺四寸四分, 其尺間有八寸, 一寸 準曲尺一寸八分。内有財、病、離、義、官、劫、害、吉也。凡人造門, 用 依尺法也。【注釈】「魯般真尺」魯般尺の一尺は曲尺の一尺四寸四分に当 たり、その中で八寸に分かれ、一寸は曲尺の一寸八分に当たる。八寸の中 には、財、病、離、義、官、劫、害、吉という八字がある。門を造る場合 には、この尺を使う。

【項目 8】「本門詩曰」本字開門大吉昌, 尺頭尺尾正相當。量來尺尾須當吉, 此到頭來財上量。【注䣋】「本門詩日」門の寸法は「本」であれば大吉で ある。尺頭から尺尾にも合う。「本」が尺頭であれば尺尾は「吉」である。 「本」が尺尾であれば尺頭は「財」である。

【項目 9】「曲尺詩(圖在後)」一白難如六白良, 若然八白亦為昌。不將般尺 來相湊, 吉少凶多必主殎。【注釈】「曲尺詩(圖在後)」一白は六白より良 いということは難しい。しかし、八白もよい。魯般尺と一緒に使わないと、 魯般尺法における「吉」の寸法は少なくて、「凶」の寸法は多いことは知 らない場は、災害がおこる。

【項目 10】「曲尺之図」曲尺者有十寸, 一寸乃十分。几遇起造、經營、開 門, 高低長短度量皆在此上。【注釈】「曲尺之図」曲尺の一尺は十寸であ る。一寸は十分である。建物を造る時、設計する時、門を造る時、高低と 長短は皆曲尺で測る。

【項目 11】「推起造向首合白吉星」其白外, 但則九紫為小吉。人要合魯般 尺與曲尺, 上下相全為好。【注釈】「推起造向首合白吉星」「白」以外、 「九」数の色は紫で、「小吉」である。曲尺と魯般尺を合わせて使う必要が ある。

【項目 18】「五架房子格」此皆壓白即言也。【注採】「五架房子格」これ らの寸法值は「圧白」ということである。

【項目 19】「詩曰」按白量材實利宜。【注釈】「詩曰」圧白尺法で部材寸 法を設計すれば良い。

注17）【項目 7】の「魯般尺詩八首」の原文は以下である。A-R の八字と八門 の対応関倸も加えた。

「財詩曰」財字臨門仔詳細，外門（A）招得外財良。若在中門（B）常自有, 積財須用大門 (C) 當。中房 (D) 若合安於上, 銀帛千箱與萬箱。 木匠若能明此理，家中福祿自㮡昌。

「病字」病字臨門招疫疾, 外門 (E) 神鬼入中庭。若在中門 $(F)$ 逢此字, 災 須輕可免危聲。更被外門相照對, 一年兩度送屍靈。於中若要無凶 禍, 厠上 (G) 無疑是好親。

「離字」離字臨門事不祥, 仔細排來在甚方。若在外門 (H) 并中戸 (I)，子 南父北自分張。房門 (J) 必主生離別, 夫婦恩情兩処忙。朝日主家 常作閙, 恓惶無地禍誰當。

「義字」 義字臨門孝順生, 一字中戸 (K) 最為真。若在都門招三婦, 廊門 (L) 淫婦變之聲。於中合字雖為吉, 也有興災害及人。若是十分無災害, 只有廍門 (M) 實可親。

「官字」官字臨門自要詳, 莫教安在大門 (N) 塲。須房公事親州唐, 富貴中 庭房自昌。若要房門 $(0)$ 生貴子, 其家必定出官郎。富貴人家有相 壓, 庶人之屋實難量

「劫字」劫字臨門不足誇, 家中日日事如麻。更有害門相照看, 凶來疊疊禍無 差。兒孫行劫身遭苦, 作事因循害却家。四惡四凶星不吉, 偷人物 件害其它。

「害」害字安門用細尋, 外門 (P) 多被外人臨。若在内門 $(Q)$ 多興禍, 家財 必被賊來侵。

「吉字」吉字臨門最是良, 中門 (R) 内外一齊強。子棌夫婦皆榮貴, 年年月
月旺虽桑。如有財門相照者, 家道興崇最吉昌。使有凶神在旁位, 也無災害 亦風光。

注18「宋」『事林広記』の中では「尺法」に関する記載は以下である。

「魯般尺法: 淮南子日、魯般即公輸般、楚人也。乃天下之巧士、能作雲梯之 械。其尺也, 以官尺一尺二寸為准、均分八寸, 其文曰財、日病、日離、日 義、日官、日塕、日害、日吉; 乃北斗中七星與輔星主之。用尺之法, 從財 字量起、雖一丈十丈皆不論、但於丈尺之内量取吉寸用之, 遇吉星則吉遇凶 星則凶。亘古及今, 公私造作, 大小方直, 皆本乎是。作門尤宜子細。又有 以官尺一尺一寸而分作長短寸者，但改吉字作本字。其余并同。

「飛白尺法: 陰陽書云, 一白、二黑、三碧、四綠、五黄、六白、七赤、八白、 九紫, 皆星之名。惟有白星最吉。用之法, 不論丈尺, 但以寸為准, 一寸, 六寸, 八寸乃吉。綐合魯般尺, 更須巧算, 参之以白, 乃為大吉。俗呼之圧 白。其尺只用十寸一尺。」

注19）[元]佚名『居家必用事類全集』居家必用事類全集丁集（明刻本）の中で は「尺法」に関する記載は以下がある。

「開門尺法: 古言, 寧去人家造百墳, 莫去人家造一門。門最利害。一家禍福率 由之, 周尺分節, 一財、二病、三離、四義、五官、六胠、七害、八吉。財與 吉為上, 官義次之, 餘無取。財吉公私内外通用。官可用之官房, 中戸出文章貴 子。庶人用之起官事, 凶。義可用之中房, 出人孝順。若在外門, 生兩姓同居, 若人家内外大小門戸, 以財、吉、義三者兼用之。主世代昌隆。特「義」不可 用之外門耳。」

「魯般尺法：「淮南子日」魯般即公輸般、楚人也。乃天下之巧士、能作雲梯 之械。其尺也, 以官尺一尺二寸為准、均分八寸, 其文曰財、日病、日離、 日義、日官、日却、日害、日吉; 乃北斗中七星與輔星主之。用尺之法, 從 財字量起、雖一丈十丈皆不論、但於丈尺之内量取吉寸用之, 遇吉星則吉遇 凶星則凶。亘古及今, 公私造作, 大小方直, 皆本乎是。作門尤宜仔細。」

注20）[明]佚名『宅寶經』（明萬暦吴勉學刻本）の中で、「尺法」に関する記 載は以下である。「九天玄女裝門尺法, 悉㠬匠人門尺所傳, 應驗可知。」 という条目がある。

注21）[明]午榮『魯班經』卷一 (清乾隆刻本) の中で、「尺法」に関する記載 は以下である。「按九天玄女装門路（格）以玄女尺算之、毎尺止得九寸有 零、却分財病離義官劫害本八位、其尺寸長短不齊。惟本門與財門相接最吉。 義門惟寺觀學舍義聚之所可裝。官門惟官府可裝。其餘民俗只粧本門與財門。 相接最吉。大抵尺法各隨匠人所傳術者、當依魯般經尺度爲法。」

注22）[清]李斗『揚州畫舫録』卷一（清乾隆六十年自然盒刻本）の中では、「尺

法」に関する記載は以下である。「古尺法為十五種 : 日周尺、日晉田父玉 尺、日梁表尺、日漢官尺、日魏尺、日晉後尺、日後魏前尺、日中尺、日後

尺、日東魏後尺、日蔡邑銅筒尺、日宋氏尺、日隋水尺、日雜尺、日梁俗間 尺、而必以周尺為之本。」

注23）『阳宅十書』中で，「尺法」に関する記載は以下である。「用門尺法： 海内相伝門尺数種, 屡経験試, 唯此尺為真。長短協度, 凶吉无差。盖昔公 輸子班, 造极木作之聖, 研穷造化之微, 故創是尺。后人名為魯班尺。非止 量門可用, 一切床房器物, 俱当用此, 一寸一分, 灼有関系者。」

注24）[元]佚名『新編魯般営造正式』の中では「凡人造門, 用依尺法也」とい う条目がある。

注25) 注 18) と同じ

注26)注 19) と同じ

注27) 注 18) と同じ

注28）[明]吴國仕『造命宗鏡集』卷十一「雑用類」（明崇禎三年呂氏搜玄齊刻

本）中で，「魯般尺法」に関する記載は以下である。「魯班尺一寸管一字 財、離、病、義、官、规、害、本内財、義、官、本四字吉餘凶。凡造門法、 惟官衙門宜用官、義、本三字吉。寺觀門宜義字吉。士庶門宜用財、義、本 三字吉。宦門宜官字大吉、餘忌不宜。」

注 29$)[$ 清 $]$ 馮桂芬『 (同治) 蘇州府志』卷十二（清光緒九年刊本）中で，「魯 般尺法」に関する記載は以下である。「情伏査部頒新弓係用營造尺五尺、 蘇省舊弓倸用魯班尺六尺。以尺數論舊弓較多一尺、賈則魯班一尺、合營造 尺僅八寸八分、以六尺計之合營造尺僅五尺二寸八分。並不足六尺之數。」 注30) [清]胡彦昇『樂律表微』卷一 (清文淵閣四庫全書本) 中で, 「魯般尺法」 に関する記載は以下である。「朱氏圖載營造尺即木匠曲尺、今木匠曲尺一 尺得營造尺九寸。嘗詢匠氏曲尺異同、答云此名魯班尺、自古至今無二尺。」 注31）[清]李斗『揚州畫舫録』卷十七（清乾隆六十年自然盈刻本）中で, 「魯 般尺法」に関する記載は以下である。「門尺有曲尺，八字尺二法。曲尺長 一尺四寸四分（為）八字尺，長八寸、毎寸準曲尺一寸八分、皆謂門尺。長 亦維均八字:財、病、離、義、官、劫、害、本也。」 注32)ここの「八字尺」は魯般尺を指す。 
注33）[清]張宗法『三農紀』卷九（清刻本）中で，「魯般尺法」に関する記載 は以下である。「木經云, 上戸門六尺六寸, 又云高五尺七寸, 濶四尺八寸, 總要合魯班尺式財、本二字。不可犯病、離、義、官、㕖、害六字, 可能获 吉。」

注34) 吉凶の比は 4 吉 4 凶であるが、さらに、大吉、小吉、小凶、大凶に分か れ、その比率は $1: 1: 1: 1$ である。

注35)注 18) と同じ

注36) [明] 吴國仕『造命宗鏡集』卷十一「雜用類」（明崇禎三年吴氏搜玄齊刻

本）中で，「圧白尺法」に関する記載は以下である。「惟子房尺曲尺以九 寸。分九部一寸爲一白、六寸六白、八寸八白、九寸九紫、皆吉。」

注37）[明]午笨『魯班經』卷二（清乾隆刻本）中で，「圧白尺法」に関する記 載は以下である。「造欄用木尺寸法度。用尋向陽木一根作楝柱、用近在人 屋在畔牛性怍寒、使牛温暖、其柱長短尺寸用壓白、不可犯在黑上。」

注38）[清]張宗法『三農紀』卷九（清刻本）中で,「圧白尺法」に関する記載 は以下である。「牛欄: 造欄須選向陽青萃木一根、作棟柱、短長尺寸宜壓白、 不可犯黑。間架宜雙勿單、高底尺寸俱宜合六白。然八亦属白、又云八敗、 故忌。」

注39）[清]李斗『揚州畫舫録』卷十七（清乾隆六十年自然盒刻本）中で, 「圧 白尺法」に関する記載は以下である。「曲尺十分為寸、一白、二黑、三碧、 四綠、五黄、六白、七赤、八白、九紫、一白也。」

注40) [清] 宮夢仁『讀書紀數略』卷一天部（清文淵閣四庫全書本）中で, 「圧 白法」に関する記載は以下である。「九宮洛書 : 一白正北、二黑西南、三 碧正東、四綠東南、五黄中宫、六白西北、七赤正西、八白東北、九紫正南。」

注41）[明]吴國仕『造命宗鏡集』卷六 (明崇禎三年吴氏搜玄齋刻本) 中で，「圧 白法」に関する記載は以下である。「三元年白例（略）、三元月白例（略）、 三元日白例（略）、三元時白例（略）年白不如月白、日白有力（方）大吉、 時白則不如也。（略）」

注42）[清]李斗『揚州畫舫録』卷十七（清乾隆六十年自然盒刻本）中で，「圧 白尺法」に関する記載は以下である。「又古裝門路用九天元女尺、其長九 寸有奇匠者繩墨三白九紫、工作大用。日時尺寸上合天星、是為圧白之法。」

注43）「魯般真尺」の一部の原文と注釈は以下である。

【項目 6】假如單扇門, 小者開二尺一寸, 壓一白, 般尺在義上。單扇門, 開二 尺八寸, 在八白, 般尺合吉上。雙扇門者, 用四尺三寸一分, 合三綠一白, 則為本 門, 在吉上。如財門者, 用四尺三寸八分, 合財門, 吉。大雙扇門, 用廣五尺六寸 六分, 合兩白, 又在吉上。今時匠人則開門, 濶四尺二寸, 乃為二黑, 般尺又在吉 上。及五尺六寸者, 則吉上。二分加六分正在吉中, 為佳也。皆用依法, 百無一 失, 則為良匠也。【注釈】例えば、単扉の門を造る場合、規模が小さいとき は、扉の幅は二尺一寸にする。すると曲尺は「一白」で、魯般尺は「義」 である。または、二尺八寸にする場合、曲尺は「八白」で、魯般尺は「吉」 である。双扉の門を造る場合、扉の幅は四尺三寸一分にする。すると曲尺 は「一白」で、魯般尺は「本」で、両方とも吉の意味になる。「財門」の 場合は、幅を四尺三寸八分にして、魯般尺は「財」であり、吉である。大 双扉の門を造る場合には、幅は五尺六寸六分にする。曲尺は二つの「六白」、 魯般尺は「吉」になる。今の工匠が門を造る時、幅は四尺二寸にする。曲 尺では「二黒」、魯般尺では「吉」である。五尺六寸の場合、曲尺は「六 白」、魯般尺は「吉」である。もし、二分上に六分を加えて、八分にすれ ば、曲尺は「八白」で「吉」になって良い。それは失敗がない方法である から、この方法を使えば良匠である。

注44) 項目 $15,18,22,24$ の原文と注釈は以下である。

【項目 15】「三架屋後連一架」造此小屋者, 切不可高大。几歩柱, 只可高一 丈零一寸。棟柱高一丈二尺一寸。叚哚五尺六寸, 間闊一丈一尺一寸, 次間一 大零一寸, 此法則相稱也。【注釈】「三架屋後連一架」この小屋を造る場 合には、絶対に規模を大きくしてはならない。歩柱の高さは高くても一丈 一寸までとする。棟柱の高さは一丈二尺一寸とする。架深は五尺六寸、中 央間は一丈一尺一寸、脇間は一丈一寸に寸る。この法則は、この形式（三 架屋後連一架）と互いにつり合うのである。

【項目 18】「五架房子格」正五架三間拖後一柱。歩用一丈零八寸, 仲高一 丈二尺八寸, 棟高一丈五尺一寸。毎叚四尺六寸。中間一丈三尺六寸, 次闊 一丈二尺一寸。地基闊陝則在人加減, 此皆壓白即言也。【注釈】「五架屋子 格」正五架三間拖後一柱という形式は、正面 3 間、側面 4 間を背面に 1 間 加えて、側面に 5 間となる。歩柱の高さは一丈八寸、仲柱の高さは一丈二 尺八寸、棟柱の高さは一丈五尺一寸に寸る。架媣は四尺六寸、中央間は一 丈三尺六寸、脇間は一丈二尺一寸にする。屋の規模は人によって加減して もよい。これ、すなわち皆圧白というのである。

【項目 22】「正七架三間格」七架堂屋, 大几架造, 合用前後, 柱高一丈二尺六
寸。棟高二丈零六寸。中間用闊一丈四尺三寸, 次闊一丈三尺六寸。尉四尺八 寸, 地基闊側、高低、深淺, 隨人意加減則為之。【注釈】「正七架三間格」 この七架堂屋の架構を造る場合には、一般的に、前（室）と後（室）を合 わせて用いる。柱高は一丈二尺六寸で、棟柱は二丈六寸である。中央間は 一丈四尺三寸、脇間は一丈三尺六寸である。架深は四尺八寸である。平面 の規模、（柱の）高さ、（奥行の）深さは、それぞれの人によって、加減 し、この架構を造るのである。

【項目 24】「正九架五間堂屋格」凡造此屋, 歩柱用高一丈三尺六寸。棟柱, 或地基廣（闊益一丈四尺八寸；叚淺者四尺三寸）, 或十分深, 高二丈二尺, 棟克妙。【注釈】「正九架五間堂屋格」この構造（正九架五間堂屋格）を 造る場合には、歩柱の高さは一丈三尺六寸である。平面の規模が広い (中 央間が間ロ一丈四尺八寸、架梁は四尺三寸）、または、十分に奥桁が深い 場合、棟柱は高さ二丈二尺にする。そうすれば、棟柱の高さは平面規模と つりあって、みごとである。

注45)それらの専用名詞の日本語注釈は以下である。

「歩柱」は正面と背面の側柱である。「棟柱」は棟通りの柱である。「仲 柱」は「歩柱」と「棟柱」間の柱である。「架梁」は梁行の柱間のことで ある。「心間」は桁行柱間のうち、中央（最大）の柱間である。「次間」 は脇間の柱間である。

注46)それらの専用名詞の日本語注釈は以下である。

総架深」は桁行総柱間である。「総面闊」は梁初総柱間である。

注47「総架哚」、「総面闊」の計算方法は以下である。

三架後連一架：「総面闊」 $=「$ 心間 $+「$ 次間」 $\times 2=111+101 \times 2=313$ 寸 三架後連一架：「総架深」 $=\lceil$ 架深」 $\times 3=56 \times 3=168$ 寸 五架拖後一柱：「総面闊」 $=\lceil$ 心間 $」+「$ 次間 $\perp \times 2=136+121 \times 2=378$ 寸 五架拖後一柱：「総架深」 $=\lceil$ 架深」 $\times 5=46 \times 5=230$ 寸 正七架：「総面闊」 $=\lceil$ 心間 $+\Gamma$ 次間 $\perp \times 2=143+136 \times 2=415$ 寸 正七架：「総架深」 $=\lceil$ 架樑」 $\times 6=48 \times 6=288$ 寸 正九架：「総架梁」 $=\lceil$ 架哚」 $\times 8=43 \times 8=344$ 寸

注48）参考文献 10） p . 147 より、「十」は「白」（吉）である。1から10ま での数字の内に、「圧白」に当てはめる数字は $1 、 6 、 8 、 10$ の四つであり、 吉比率は $40 \%$ である。従って、任意数字は圧白尺法における吉になる可能 性は 40\%である。

注49) 魯般尺の一尺の八字の内に、4つは吉、4つは凶であり、吉比率は $50 \%$ である。従って、任意数字は魯般尺における吉になる可能性は $50 \%$ ある。 注50)図 6 は表 5 に出てくる寸法值の吉凶判断を説明している。一番左の上を 「0」として、一番右下が「441」となるが、便宜上、魯般尺の文字のため (例えば官と却の間)、これを 4 本に分けて載せている。例えば、101 寸 の場合、圧白尺法の目盛を見ると、「一白」になっており、圧白している。 魯般尺の目盛を見ると「財」になっており、從って、101寸は、どちらの 尺法でも良い数字ということになる。

注51）中国南部においては、貫構造となるため、梁、貫などの部材長は、柱心 でとる。又、工匠は部材を計る時に、仕口も含めた全長でとる。 注52) 注 43) と同じ

注53）参考文献 15)、21)によって、『新編魯般営造正式』の編箕の祖本は 本書に書名が記載された『魯般経』と『営造正式』と推測した。その二冊 の本は現存していないが、尺法内容との関倸について、圧白尺法と魯般尺 法を併せて架構に用いる方法は『魯般経』の内容から、圧白尺法のみ架構 に用いる方法は『営造正式』の内容からであると推測したが、今後更なる 詳しい研究が期待される。

注54）『新編魯般営造法式』における「古」と「今」の技術の差異に関する記 載は以下である。

【項目 8】「本門詩日」福祿乃為門上致, 子孫必出好兒郎。時師依此仙賢造, 千倉萬盧有餘糧。【項目 13】「推匠人起工格式」今有晚学木匠, 則先将棟 柱用工, 則不按魯般之法。【項目 25】「詩日」䔆按仙師真尺寸, 管教富貴足 莊田。時人若不依仙法, 致使人家兩不然。【項目 26】「秋迁架」秋迁架, 今 人偷棟柱, 為之吉, 以如此造。其中創閑, 要坐起処, 可則依此格尽好。【項目 30】「詩日」此物分明端正妾, 暗中為禍少人知。只因匠者多歳素, 也是時師 不細詳。使得家門長退落, 縁他屋主太隈衰。從今若要兒孫好, 除是從頭改過 為。【項目 39】「諸様垂魚正式」今人又嘆作繁針, 如用此, 又用做遮風及偃 桷者, 方可使之。今之匠人又有不使垂魚者, 只使直板, 作如意頭垂下者, 亦好。 如不使, 則又不妨。如不做如意只作雕云様者, 亦好。皆在主人之所好也。【項 目 40】「驼峯正格」或今之人多只愛使斗, 立叉童, 乃為時格也。【項目 42】 「五架后拖两架」五架屋後添両架, 此正按古格。今時人喚做前浅后哚之説, 乃住坐笑隠也。如造正五架者, 必是其基地如此, 別有実格式可験之也。 